INT. J. RADIAT. BIOL., 1971, VOL. 19, No. 4, 399-400

\title{
Effectiveness of Zn-DTPA in removal of plutonium from rats
}

\author{
A. SEIDEL, V. VOLF and A. CATSCH \\ Institut für Strahlenbiologie, Kernforschungszentrum, \\ 75 Karlsruhe 1, Postfach 3640, Germany
}

(Received 16 January 1971; accepted 22 January 1971)

The use of the $\mathrm{Zn}$-chelate of diethylenetriaminepentaacetate (DTPA) instead of Ca-DTPA for removal of internally-deposited radionuclides has been suggested (Catsch 1968, Catsch, Lê and Chambault 1964). This recommendation is based on the fact that $\mathrm{Zn}-\mathrm{DTPA}$ has a markedly lower toxicity than Ca-D'TPA (Catsch 1964, Catsch and Wedelstaedt 1960, Seidel 1970, Smith 1970, Weber 1969), but is only slightly less effective in mobilizing ${ }^{91} \mathrm{Y}$ and ${ }^{144} \mathrm{Ce}$ from the body (Catsch et al. 1964). Meanwhile, both chelates were found to be equally effective in removing ${ }^{147} \mathrm{Pm}$ (Smith 1970), whereas the influence Ca-DTPA on the excretion of ${ }^{239} \mathrm{Pu}$ seems to surpass that of the $\mathrm{Zn}$-chelate (Smith 1966). In the latter study, chelate treatment was initiated 1 hour after injection of ${ }^{239} \mathrm{Pu}$; the main objective of $\mathrm{Zn}-\mathrm{DTPA}$, however, is the delayed treatment situation (Catsch 1968). In view of the great importance of ${ }^{239} \mathrm{Pu}$, a reinvestigation was advisable.

Female albino rats averaging $190 \mathrm{~g}$ in weight were injected intravenously with $0.2 \mu \mathrm{Ci}$ monomeric ${ }^{239} \mathrm{Pu}(\mathrm{IV})(0.25 \mathrm{ml}$., $\mathrm{pH} 8 \cdot 5)$. Monomeric $\mathrm{Pu}$ was prepared according to Taylor (personal communication) by diluting the stock solution of $\mathrm{Pu}\left(\mathrm{NO}_{3}\right)_{2}$ with sodium citrate and filtration through millipore filter (pore diameter $25 \mathrm{~nm}$ ) before injection. $\mathrm{Na}_{3}[\mathrm{Ca}-\mathrm{DTPA}]$ and $\mathrm{Na}_{3}\left[\mathrm{Zn}-\mathrm{D}^{\prime} \mathrm{TPA}\right]$, respectively, were injected intraperitoneally on the 6 th, 8 th and 11 th day; the dosage equalled $1 \mathrm{mmol} \times \mathrm{kg}^{-1} \times \mathrm{d}^{-1}(2 \mathrm{ml}$., $\mathrm{pH} 7 \cdot 4)$. The $\alpha$-activity of tissue samples was assayed by liquid scintillation counting (Seidel and Volf, in press).

\begin{tabular}{|c|c|c|c|c|c|}
\hline & $\begin{array}{l}\text { Control } \\
\text { 6th day }\end{array}$ & $\begin{array}{r}\mathrm{C} \\
(0 \cdot 9 \text { per } \\
13\end{array}$ & $\begin{array}{l}\text { ntrol } \\
\text { cent } \mathrm{NaCl} \text { ) } \\
\text { h day }\end{array}$ & $\begin{array}{c}\text { Ca-DTPA } \\
\text { 13th day }\end{array}$ & $\begin{array}{c}\text { Zn-DTPA } \\
\text { 13th day }\end{array}$ \\
\hline Liver & $14.6 \pm 0.88$ & $7 \cdot 15$ & \pm 0.71 & $1.44 \pm 0.07$ & $1.64 \pm 0.09$ \\
\hline Spleen & $0.24 \pm 0.02$ & $0 \cdot 32$ & \pm 0.02 & $0 \cdot 16 \pm 0.01$ & $0.18 \pm 0.01$ \\
\hline Kidneys & $1.04 \pm 0.04$ & $0 \cdot 74$ & \pm 0.05 & $0.45 \pm 0.04$ & $0.36 \pm 0.02$ \\
\hline Lung & $0 \cdot 14 \pm 0 \cdot 01$ & $0 \cdot 12$ & \pm 0.01 & $0 \cdot 047 \pm 0 \cdot 003$ & $0.054 \pm 0.005$ \\
\hline Thyroid & $0.22 \pm 0.003$ & $0 \cdot 016$ & \pm 0.0005 & $0 \cdot 009 \pm 0.001$ & $0.008 \pm 0.001$ \\
\hline Adrenals & $0.012 \pm 0.001$ & 0.013 & \pm 0.001 & $0.006 \pm 0.001$ & $0.0062 \pm 0.0003$ \\
\hline Ovaries & $0.017 \pm 0.001$ & 0.016 & \pm 0.002 & $0.010 \pm 0.001$ & $0.009 \pm 0.001$ \\
\hline $\begin{array}{l}\text { Skeleton } \\
n\end{array}$ & $62 \cdot 0 \pm 1 \cdot 09$ & $56 \cdot 5$ & \pm 0.54 & $41 \cdot 5 \quad \pm 2 \cdot 20$ & $40.9 \pm 0.79$ \\
\hline
\end{tabular}

${ }^{239} \mathrm{Pu}$-content of the organs (percentage of ${ }^{239} \mathrm{Pu}-\mathrm{dose}$ ). Means \pm S.E. $\quad n=$ number of animals. 
As can be seen from the table, both chelates show virtually equal efficacy in lowering the ${ }^{239} \mathrm{Pu}$-content of the organs. This is in keeping with recent results obtained by Smith (personal communication) with ${ }^{238} \mathrm{Pu}$. The favourable result of our study prompted us to start a more detailed investigation, which will be concerned with the action of $\mathrm{Zn}-\mathrm{DTPA}$ on monomeric and polymeric ${ }^{239} \mathrm{Pu}$ as influenced by treatment schedule.

\section{REFERENCES}

Catsch, A., 1964, Arch. exp. Path. Pharmak., 246, 316; 1968, Dekorporierung radioaktiver und stabiler Metallionen (München: K. Thiemig).

Catsch, A., LÊE, D. Kh., and Chambault, D., 1964, Int. F. Radiat. Biol., 8, 35.

Catsch, A., and Wedelstaedt, E. von, 1960, Experientia, 21, 210.

SEIDEL, A., 1970, Strahlentherapie, 139, 603.

SeIDEL, A., and Volf, V. (in the press).

SMith, V. H., 1966, BNWL-280, 81; 1970, BNWL-1050, part 1, 5.3.

WeBER, K. M., 1969, Z. ges. exp. Med., 150, 354. 